\title{
CALCULATION METHOD FOR VARIABLE KINETIC AND DIFFUSION EQUATION COEFFICIENTS FOR ADSORPTION OF SULFONOL IN THE NONLINEAR ISOTHERM REGION
}

\author{
G.S.Aliyev, R.N.Najiyeva \\ M.Nagiyev Institute of Catalysis and Inorganic Chemistry, of NAS of Azerbaijan \\ chemproblem@mail.ru
}

Received 03.04.2019

\begin{abstract}
The results of studies of the kinetic and diffusion coefficients for the adsorption of surfactants on oilbearing rocks in the nonlinear region of the isotherm are cited. These parameters allow you to select an effective solution filtration mode, set the motion velocity of concentration points of the adsorption front, control the longitudinal-temporal distribution of surfactant concentrations on the solid and mobile phases of the bed depending on the initial concentration and the flow rate of the solution. The paper presents a numerical method for determining the parameters of the equations of a mathematical model of the adsorption of surfactants - sulfonol from an aqueous solution in oil sand using experimental data. It takes into account that the kinetics coefficient and the effective diffusion coefficient in a porous medium depend on the concentration of the target component. With using experimental data and the developed methodology, empirical equations for the kinetics coefficient and the effective diffusion coefficient of the process are determined. It is determined that these coefficients vary within very large limits. As a result of the research, the adequacy of the calculated data of the adsorbate and the adsorptive to experiment al. The maximum average deviation does not exceed $8 \%$.
\end{abstract}

Keywords: adsorption, porous medium, surfactants, sulfonol, mathematical model, kinetics coefficient, effective diffusion coefficient.

\section{https://doi.org/10.32737/0005-2531-2019-3-57-61}

Many tasks related to the use of surfaceactive substances (surfactants) in the field of oil recovery remain little studied. These include the management of the operation of water-flooding of surfactant solutions, which significantly depends on an integrated approach to process modeling. An integrated approach is understood as a combination of experimental and theoretical studies, the development of optimal engineering and economic recommendations for specific field conditions. The solution of these problems is unthinkable without mathematical modeling of the process. One of the difficulties of using the mathematical model of isothermal adsorption of surfactants is the determination of the adsorption and diffusion parameters of the equations of the model [1-6].

These parameters allow you to select an effective solution filtration mode, set the motion velocity of concentration points of the adsorption front, control the longitudinal-temporal distribution of surfactant concentrations on the solid and mobile phases of the bed depending on the initial concentration and the flow rate of the solution.
Note that in many studies, when describing adsorption-diffusion processes, such parameters as the effective diffusion coefficient and the kinetics coefficient are either specified or determined under static conditions by the traditional method.

It follows from the above that for the study of the regularities of the effect of temperature on the adsorption-diffusion processes, the determination of their parameters is very important and is of great practical and scientific importance.

Therefore, it becomes necessary to determine the effective diffusion coefficient and the kinetics coefficient, which depend on the concentration of the target component, which significantly complicates the mathematical formulation of this process, and often makes it impossible to obtain analytical solutions. Therefore, it is necessary to develop numerical methods for determining these parameters.

This paper presents a numerical method for determining the parameters of the equations of a mathematical model for the adsorption of 
surfactant sulfonol from an aqueous solution in oil sand using experimental data.

The experiments were carried out on a bed model, the main part of which was an experimental column $50 \cdot 10^{-2} \mathrm{~m}$ long with a cross section of $d=10.5 \cdot 10^{-3} \mathrm{~m}^{2}$. The porous medium was created from the rocks of the Kirmakin suite (KS). The average diameter of the grains of rocks $\mathrm{KS}$ is $d=10.5 \cdot 10^{-3} \mathrm{~m}$. As a surfactant solution, a $3 \%$ aqueous solution was used. Adsorption column was filled with sand and at a constant linear velocity $V=0.031 \cdot 10^{-2} \mathrm{~m} / \mathrm{s}$, surfactant solutions were pumped into the formation model. The change in the concentration of the solution at the exit of the porous medium was determined from the samples taken by measuring the surface tension. The experiment was considered complete when the last working layer reaches equilibrium.

Also, experiments were conducted with columns long $1 \mathrm{~m} ; 2 \mathrm{~m}$ and $2.5 \mathrm{~m}$ under the same conditions as for the column length $50 \cdot 10^{-2} \mathrm{~m}$.

Tables 1-3 show some of the results of the experimental data (columns 1-4). Each of these options differs only in the length of the bed model.

Table 1. The results of calculations for the identification of parameters of the adsorption process sulfonol on sand $\mathrm{KS}$ with $L=0.5 \mathrm{~m}, C_{0}=30 \mathrm{mg} / \mathrm{g}, V=0.031 \cdot 10^{-2} \mathrm{~m} / \mathrm{s}, a_{0}=$ $24 \mathrm{mg} / \mathrm{g}$.

\begin{tabular}{|c|c|c|c|c|c|}
\hline$t, s$ & $\begin{array}{c}a_{\mathrm{p}}, \\
\mathrm{mg} / \mathrm{g}\end{array}$ & $\begin{array}{c}C_{\text {eq. }}, \\
\mathrm{mg} / \mathrm{g}\end{array}$ & $\begin{array}{c}C^{\exp }, \\
\mathrm{mg} / \mathrm{g}\end{array}$ & $\begin{array}{c}C^{\mathrm{cal}}, \\
\mathrm{mg} / \mathrm{g}\end{array}$ & $\begin{array}{l}\begin{array}{l}\text { Relative errors, } \\
\left|C^{\exp }-C^{\text {cal }}\right| \\
\end{array} .100 \%\end{array}$ \\
\hline 1 & 2 & 3 & 4 & 5 & 6 \\
\hline 0 & 0 & 0 & 0 & 0 & 0 \\
\hline 1200 & 5.5 & 3.3 & 7.0 & 7.16 & 2.29 \\
\hline 1800 & 10.4 & 7.0 & 13.0 & 14.01 & 7.79 \\
\hline 2100 & 16.0 & 13.4 & 20.0 & 18.66 & 6.7 \\
\hline 2400 & 19.3 & 18.4 & 24.0 & 22.55 & 6.0 \\
\hline 2700 & 20.6 & 21.0 & 25.6 & 25.38 & 0.89 \\
\hline 3000 & 21.0 & 22.0 & 26.4 & 27.21 & 3.09 \\
\hline 3600 & 21.6 & 23.5 & 27.0 & 28.81 & 6.70 \\
\hline
\end{tabular}

Table 2. Same as in table 1, with $L=1.0 \mathrm{~m}$

\begin{tabular}{|c|l|l|l|l|l|}
\hline 1 & \multicolumn{1}{|c|}{2} & \multicolumn{1}{c|}{3} & \multicolumn{1}{c|}{4} & \multicolumn{1}{c|}{5} & \multicolumn{1}{c|}{6} \\
\hline 0 & \multicolumn{1}{c|}{0} & \multicolumn{1}{c}{0} & \multicolumn{1}{c}{0} & 0 & \multicolumn{1}{c|}{0} \\
2400 & 3.2 & 2.2 & 4.2 & 4.24 & 0.95 \\
3300 & 6.3 & 4.0 & 8.0 & 7.96 & 0.5 \\
3900 & 10.0 & 6.6 & 12.6 & 12.57 & 0.24 \\
4500 & 14.8 & 11.8 & 18.6 & 18.54 & 0.32 \\
5100 & 18.7 & 17.4 & 23.4 & 23.59 & 0.81 \\
5700 & 21.6 & 23.2 & 26.8 & 26.68 & 0.45 \\
6000 & 22.5 & 25.0 & 28.0 & 27.76 & 0.86 \\
6600 & 23.0 & 26.5 & 28.6 & 28.86 & 0.91 \\
\hline
\end{tabular}

Table 3. Same as in table 1, with $L=2 \mathrm{~m}$

\begin{tabular}{|c|l|l|l|l|l|}
\hline 1 & \multicolumn{1}{c|}{2} & \multicolumn{1}{c|}{3} & \multicolumn{1}{c|}{4} & \multicolumn{1}{c|}{5} & \multicolumn{1}{c|}{6} \\
\hline 0 & 0 & 0 & 0 & 0 & 0 \\
2400 & 1.6 & 1.3 & 2.3 & 2.45 & 6.52 \\
3000 & 2.0 & 1.5 & 2.8 & 3.31 & 18.21 \\
3600 & 3.5 & 2.3 & 4.5 & 4.54 & 0.89 \\
4200 & 5.0 & 3.0 & 6.4 & 6.36 & 0.63 \\
4800 & 7.6 & 4.8 & 9.7 & 9.09 & 6.29 \\
5400 & 10.4 & 7.0 & 13.0 & 12.90 & 0.77 \\
6000 & 13.7 & 10.4 & 17.2 & 17.62 & 2.44 \\
6600 & 18.0 & 16.4 & 22.4 & 22.47 & 0.31 \\
7200 & 21.3 & 22.4 & 26.6 & 26.44 & 0.60 \\
7800 & 23.6 & 28.2 & 29.4 & 29.09 & 1.05 \\
8400 & 23.9 & 23.9 & 29.9 & 30.45 & 1.84 \\
\hline
\end{tabular}

Table 4. Same as in table 1 , with $L=2.5 \mathrm{~m}$

\begin{tabular}{|l|l|l|l|l|l|}
\hline \multicolumn{1}{|c|}{1} & \multicolumn{1}{c|}{2} & \multicolumn{1}{c|}{3} & \multicolumn{1}{c|}{4} & \multicolumn{1}{c|}{5} & \multicolumn{1}{c|}{6} \\
\hline 0 & 0 & 0 & 0 & 0 & 0 \\
3300 & 2.3 & 1.7 & 3.0 & 3.55 & 18.33 \\
4200 & 4.2 & 2.6 & 5.4 & 5.25 & 2.78 \\
5100 & 6.8 & 4.3 & 8.6 & 8.26 & 3.95 \\
6000 & 10.7 & 7.3 & 13.6 & 13.18 & 3.09 \\
6600 & 14.2 & 11.0 & 17.8 & 17.72 & 0.45 \\
7200 & 17.4 & 15.3 & 21.8 & 22.06 & 1.19 \\
7800 & 20.0 & 19.6 & 25.0 & 25.43 & 1.72 \\
8700 & 23.1 & 26.7 & 28.8 & 28.42 & 1.32 \\
9300 & 23.7 & 28.3 & 29.7 & 29.39 & 1.04 \\
10200 & 23.9 & 29.6 & 29.9 & 29.98 & 0.27 \\
\hline
\end{tabular}

Analysis of experimental data in the field of surfactant adsorption on quartz and oil sands showed that the processes of surfactant adsorption on these sands are best described by the model of non-equilibrium adsorption dynamics on a fixed bed of an adsorbent, which includes the differential equation of the material balance of the adsorbed substance during onedimensional movement of the solution in a porous medium, equations of kinetics and equilibrium adsorption. It takes into account that the kinetics coefficient and the effective diffusion coefficient in a porous medium depend on the concentration of the target component: material balance equations

$$
m \frac{\partial C}{\partial t}+m V \frac{\partial C}{\partial x}+(1-m) \frac{\partial a}{\partial t}=m \frac{\partial}{\partial t_{x}}\left[D_{e}(C) \frac{\partial C}{\partial x}\right]
$$

equations of kinetics and equilibrium adsorption

$$
\begin{aligned}
& \frac{1-m}{m} \frac{\partial a}{\partial t}=\beta(C) \cdot\left[C-\phi\left(a_{\mathrm{eq}}\right)\right], \\
& C_{e q}=\phi\left(a_{e q}\right),
\end{aligned}
$$


where $C, a ; C_{e q}, a_{e q}$ - nonequilibrium and equilibrium concentrations of adsorption and adsorbate, respectively; $v$ - linear flow rate of surfactant solution injected into the reservoir; $m-$ reservoir porosity; $\beta(C)$ - kinetic coefficient; $D_{e}(C)$ - effective diffusion coefficient; $t$ - time; $x$ - adsorbent bed height coordinate; $\varphi$-adsorption equilibrium function.

With the experimental scheme carried out, the initial and boundary conditions have the form:

$$
\begin{gathered}
C(0, t)=C_{0} ; \quad a(x, 0)=0 ; \quad C(x, 0)=0 ; \\
\text { at } \quad x=L \quad \frac{\partial C}{\partial x}=0 ; \quad C(L, t)=C^{\exp }(t) \quad(5)
\end{gathered}
$$

where $C_{0}$ - the initial concentration of the adsorptive at the entrance of the absorber; $C^{\exp }-$ concentration of surfactant sulfonol in solution at the exit from the adsorbent; $L$ - adsorption column length.

The task of determining the effective diffusion coefficient and kinetic adsorption coefficient, based on experimental data, is reduced to solving a system of differential equations (1)-(5).

In view of the nonlinearity of the differential equations (1)-(5), obtaining an exact analytical solution seems impossible. Therefore, the problem is solved numerically by the grid method.

The task of determining $D_{\mathrm{e}}(C)$ and $\beta(C)$ reduces to minimizing the functional

$$
I(D, \beta)=\int_{0}^{T}\left[C(L, t)-C^{\exp }(t)\right]^{2} d t
$$

where $T$-duration of adsorption. $C(L, t)$ is determined from the solving problem (1)-(5).

By specifying the desired functions in the form of polynomials

$$
\beta(C)=\sum_{i=0}^{n} b_{i} C^{i} ; \quad D(C)=\sum_{k=0}^{v} d_{i} C^{k}
$$

transform the problem of determining these functions to the definition of constant coefficients $b_{i}, d_{k}$.

The minimization of the functional $I(D, \beta)$ is produced by the method of coordinate descent.

For the numerical solution of the problem, its difference analog was written, choosing uniform in $x$ and uneven in t steps. The choice of uneven pitch $t$ is associated with experimental data, each time layer is selected in accordance with the measurements made on the experimental setup.

Thus, the difference analog of the initial system of equations (1)-(7) for each $j+1$-th time layer has the form:

$$
A_{1} C_{i+1}^{j+1}-B_{1} C_{i+1}^{j+1}+F_{1} C_{i-1}^{j+1}=-E_{1}, i=\overline{2, N-1},
$$

Where

$$
\begin{aligned}
& A_{i}=\tau_{(4)} \cdot h^{-2} D\left(C_{i+1}^{j}\right)-v \tau_{j} \cdot h^{-1} \\
& F_{i}=\tau_{j} \cdot h^{-2} D\left(C_{i}^{j}\right) \\
& B_{i}=A_{i}+F_{i}+1+\tau_{i} \beta\left(C_{i}^{j}\right) \\
& E_{i}=C_{i}^{j}+\tau_{j} \beta\left(C_{i}^{j}\right) C_{i}^{j+1} ; h=L / N ; \tau_{j}=t_{j+1}-t_{j} .
\end{aligned}
$$

From (4), respectively, we obtain:

$$
C_{i}^{1}=0 ; \quad C_{i}^{j+1}=C_{0} ; \quad C_{N}^{j+1}-C_{N-1}^{j+1}=0 .
$$

Problem (8)-(9) is solved by the sweep method [7].

Integral (6) is calculated by the trapezoid method [8].

On the basis of experimental data for surfactant, calculations were made according to a compiled program, the results of which are presented in tables $1-4$.

As a result of numerical calculations for the desired functions, the following empiric formulas are obtained:

$$
D_{e}(C)=d_{0}+d_{2} C^{2}+d_{3} C^{3} ; \quad \beta_{0}(C)=b_{0}+b_{2} C^{2} .
$$

The value of their coefficients are given in table 5 .

Table 5. The values of the coefficients of polynomials

\begin{tabular}{|l|l|l|l|l|l|}
\hline \multicolumn{1}{|c|}{ Options } & $\begin{array}{c}\mathrm{d}_{0} \cdot 10 \\
\mathrm{~m}^{2} / \mathrm{c}\end{array}$ & $\begin{array}{c}\mathrm{d}_{2} \cdot 10^{-4} \\
\mathrm{~m}^{2} / \mathrm{c}\end{array}$ & $\begin{array}{c}\mathrm{d}_{3} \cdot 10^{-5} \\
\mathrm{~m}^{2} / \mathrm{c}\end{array}$ & $\begin{array}{c}\mathrm{b}_{0} \cdot 10^{-5} \\
\mathrm{~m}^{2} / \mathrm{c}\end{array}$ & $\begin{array}{c}\mathrm{b}_{2} \cdot 10^{-7} \\
\mathrm{~m}^{2} / \mathrm{c}\end{array}$ \\
\hline $1(L=0.5 \mathrm{~m})$ & 0.4494 & 8.1042 & 1.0081 & 12.188 & -1.1277 \\
$2(L=1 \mathrm{~m})$ & 0.06758 & 13.2 & 3.7984 & 14.382 & -2.7015 \\
$3(L=2 \mathrm{~m})$ & 0.23305 & 8.316 & 2.7294 & 0.15964 & -1.3918 \\
$4(L=2.5 \mathrm{~m})$ & 0.55183 & 43.641 & 6.8929 & 1.0773 & -1.7827 \\
\hline
\end{tabular}

\section{The results and discussion}

As a result of the research, we came to the conclusion that the developed numerical methods for determining the parameters of the equations of mathematical models of the adsorption of surfactants on oil-bearing and quartz sands provide the adequacy of the calculated data of the adsorbate and the adsorptive experiment. 


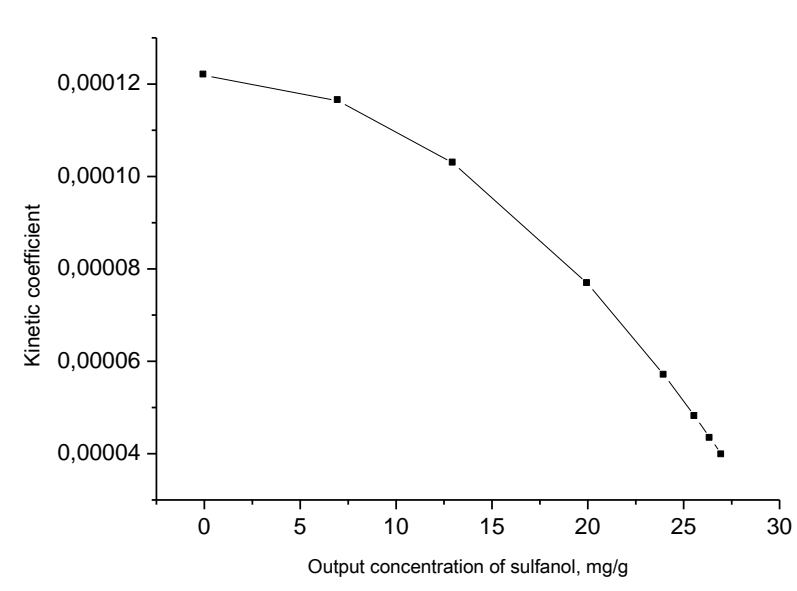

Fig. 1. The dependence of the kinetic coefficient on the output concentration of sulfonol.

The maximum average deviation does not exceed $8 \%$.

The identification of the parameters by the method led to interesting results that are of practical importance in calculating the adsorption processes of surfactants on oil-bearing rocks. As can be seen from Figure 1, the kinetic coefficient, which reflects the mass transfer between the phases, has a maximum value at the beginning of the process, that is, when the surfactant concentration in the mobile phase has a minimum value. In other words, at the moment when the surfactant traces in the mobile phase reach a certain section of the bed, here the mass exchange between the phases proceeds at maximum speed, since the absorber has active centers that are still free. As the pores of the formation granules are filled in the mobile phase, the concentration of surfactants increases, the kinetics of the absorption process decreases. At the moment of complete saturation of the bed, i.e., when equilibrium of surfactant concentrations between phases is reached, the coefficient becomes zero. This picture is repeated in all sections of the reservoir layer.

Figure 2 shows the dependence of the effective diffusion coefficient on changes in the concentration of surfactants in a solution, which reflects the longitudinal transfer on the account of molecular diffusion and convective transfer. As can be seen from the figure, the effective diffusion coefficient increases with increasing surfactant concentration in the solution. He gets

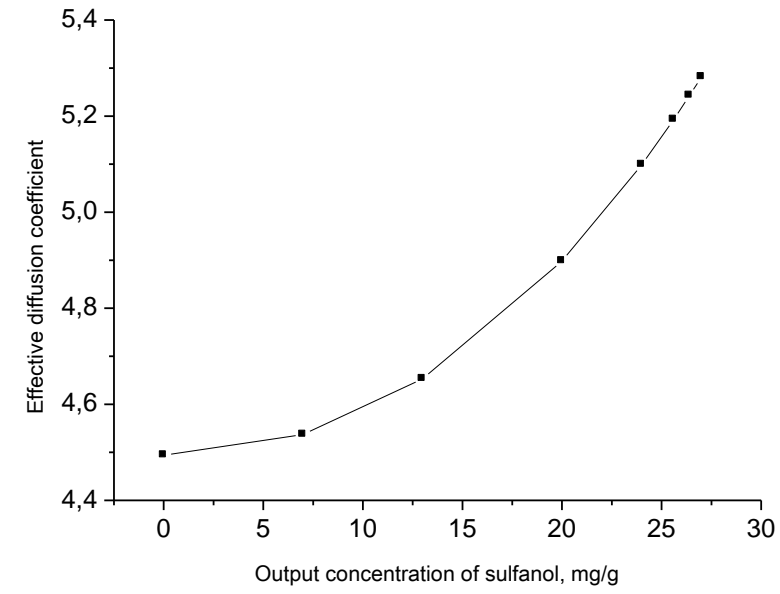

Fig. 2. The dependence of the effective diffusion coefficient on the output concentration of sulfonol.

the maximum value when reaching a concentration in the mobile phase equal to the initial concentration of surfactant in the solution, and when traces reach it to a given point of the section of the reservoir, here the diffusion in the fluid goes slightly. In this section of the bed, the surfactant concentration increases, because, as a result of adsorption, the pores of the bed granules gradually saturate, and the effective diffusion coefficient, naturally, increases nonlinearly by parabolic regularity, until equilibrium surfactant concentrations between the phases.

Thus, analyzing the data obtained, we came to the main conclusion, which confirms the great danger of assuming the constancy of the kinetic and diffusion coefficients of the equations of the model of adsorption processes. In this paper, the change of these coefficients is determined in very large limits.

\section{References}

1. Petrov N.A., Sultanov V.G., Konesev V.G., Davydova I.N. Povyshenie kachestva pervichnogo i vtorichnogo vskrytiia neftianykh plastov. $\mathrm{SPb}$.: Nedra, 2007. $544 \mathrm{~s}$.

2. Derkach S.R., Berestova G.I., Motyleva T.A. Vestn. Mooremanskogo Gos. tekhnich. un-ta. 2010. T. 13. № 4-1. C. 784-792.

3. Musina D.N., Vagapov B.R. Vest. Tekhnologicheskogo un-ta. 2016. T. 19. № 12. C. 63-67.

4. Jeppu G.P. and Clement T.P. J. Contaminant Hydrology. 2012. V. 129-130. P. 46-53.

5. Bu-Yao Zhu, Tiren Gu. J. Chem. Soc. Faraday Transactions 1. 1989. V. 85. P. 3813-3817. 
6. Duro R., Souto C., Gómez-Amoza J.L., Martínez-Pacheco R., Concheiro A.. Journal Drug Development and Industrial Pharmacy. 1999. V. 25. P. 817-829.
7. Boglaev Iu.P. Vychislitelnaia matematika i programmirovanie. M.: Vyssh. Shkola. 1990. 544 s.

8. Bakhvalov N.S., Zhidkov N.P., Kobelkov G. M. Chislennye metody. 6-e izd. M.: BINOM. Laboratoriia znanii, 2008. $636 \mathrm{~s}$.

\title{
SULFONOLUN ADSORBSIYA PROSESİ ÜÇÜN DəYIŞ̧N KINETIK Və DIFFUZIYA ĐMSALLARININ IZOTERMIN QEYRI-XəTTI OBLASTINDA HESABLANMASI METODIKASI
}

\author{
Q.S.Oliyev, R.N.Naciyeva
}

Bu məqalədə səthi-aktiv maddələrin neftdaşıyıcı laylarda adsorbsiya prosesi üçün izotermin qeyri-xətti oblastında kinetika və diffuziya əmsallarının tədqiqinin nəticələri verilmişdir. Bu parametrlər məhlulun süzülməsinin effektiv rejimlərinin seçilməsinə, adsorbsiya cəbhəsininn qatılıq nöqtələrinin hərəkət sürətinin qurulmasına, SAM qatılığının layın bərk və hərəkət edən fazalarında başlanğıc qatılıqdan və məhlul axınının sürətindən asılı olaraq uzununa və zamana görə paylanmasını idarə etməyə imkan verirlər. Məqalədə SAM - sulfonolun sulu məhluldan neftdaşıyıcı qumlarda adsorbsiya prosesinin riyazi modelinin parametrlərini təcrübi verilənlərin köməyi ilə təyin edən ədədi üsul verilmişdir. Burada kinetika və effektiv diffuziya əmsallarının məsaməli mühitdə sulfonolun qatıllı̆ından asılı olması nəzərə alınıb. Təcrübi verilənlərin və işlənib hazırlanmış metodikanın köməyi ilə kinetik və effektiv diffuziya əmsalları üçün empirik tənliklər alınmışdır. Təyin edilmişdir ki, bu əmsallar səthi-aktiv maddələrin qatıllı̆ından asılı olaraq böyük intervalda dəyişirlər. Tədqiqatların nəticəsində belə bir nəticə alınıb ki, SAM-ların neftdaşıyıcı və kvars qumlarında adsorbsiya prosesinin riyazi modelinin tənliklərinin əmsallarını təyin etmək üçün işlənib hazırlanmış metodika adsorbatın və adsorbtivin hesabi qiymətlərinin təcrübi verilənlərlə adekvatlığını təmin edir. Maksimal orta xəta 8\%-dən çox deyil.

Açar sözlar: adsorbsiya, masamali mühit, sathi-aktiv madda, sulfonol, riyazi model, kinetika amsal, effektiv diffuziya amsall.

\section{МЕТОДИКА РАСЧЕТА ПЕРЕМЕННЫХ КИНЕТИЧЕСКИХ И ДИФФУЗИОННЫХ КОЭФФИЦИЕНТОВ УРАВНЕНИЙ ДЛЯ АДСОРБЦИИ СУЛЬФОНОЛА В НЕЛИНЕЙНОЙ ОБЛАСТИ ИЗОТЕРМЫ}

\section{Г.С.Алиев, Р.Н.Наджиева}

Приведены результаты исследований кинетических и диффузионных коэффициентов для адсорбции поверхностно-активных веществ на нефтеносных породах в нелинейной области изотермы. Эти параметры позволяют выбирать эффективный режим фильтрации раствора, устанавливать скорость движения концентрационных точек фронта адсорбции, управлять продольно-временным распределеннием концентраций ПАВ на твердой и подвижной фазах пласта в зависимости от начальной концентрации и скорости потока раствора. В работе численным методом проведена определение параметров уравнений математической модели адсорбции ПАВ - сульфонола из водного раствора на нефтеносном песке с использованием экспериментальных данных. При этом учитывается зависимость коэффициента кинетики и эффективного коэффициента диффузии в пористой среде зависят от концентрации целевого компонента, разработан метод, на основе которого с помощью экспериментальных данных определены эмпирические уравнения для коэффициента кинетики и эффективного коэффициента диффузии процесса. Доказано, что эти коэффициенты меняются в очень больших пределах. В результате исследования показана адекватность расчетных данных адсорбата и адсорбтива экспериментальным. Максимальное среднее отклонение не превышает $8 \%$.

Ключевые слова: адсорбиия, пористая среда, поверхностно-активные вещества, сульфонол, математическая модель, коэффициент кинетики, эффективный коэффициент диффузии. 